\title{
Severe Combined Immunodeficiency with Absence of T, Normal B Cells
}

National Cancer Institute

\section{Source}

National Cancer Institute. Severe Combined Immunodeficiency with Absence of $T$,

Normal B Cells. NCI Thesaurus. Code C61239.

An inherited, severe immunodeficiency disorder characterized by abnormalities in the development and function of $\mathrm{T}$ cell immunity. The peripheral $\mathrm{T}$ lymphocytes are absent or in very low counts. The B lymphocyte counts are normal. 